GRASAS Y ACEITES 65 (4)

October-December 2014, e043

ISSN-L: 0017-3495

doi: http://dx.doi.org/10.3989/gya.0351141

\title{
Chemical properties of virgin olive oil from Iranian cultivars grown in the Fadak and Gilvan regions
}

\author{
M. Homapour ${ }^{1}$, M. Ghavami ${ }^{1, \bowtie}$, Z. Piravi- $\operatorname{Vanak}^{2}$ and S.E. Hosseini ${ }^{1}$ \\ ${ }^{1}$ Food Science and Technology Department, College of Food Science and Technology, \\ Science and Research Branch, Islamic Azad University, Tehran, Iran \\ ${ }^{2}$ Institute of Standards and Industrial Research of Iran Karaj, Iran \\ ${ }^{\otimes}$ Corresponding author: mehrdad_ghavami@yahoo.com
}

Submitted: 24 March 2014; Accepted: 2 June 2014

\begin{abstract}
SUMMARY: The aim of this study is to evaluate the chemical compositions (total phenol, fatty acid, sterolic compounds) of Iranian virgin olive oil (Zard, Rowghani, Mari) cultivated in the Gilvan (Zanjan Province) and Fadak (Qom Province) regions. Total phenols were determined using the Folin-Ciocalteu assay. Fatty acid and sterol profiles were also analyzed using gas chromatography. In most cases, significant effects $(P<0.05)$ of cultivars and locations were detected by the chemical composition of the oil samples. The fatty acid analysis indicated that the Mari variety from Gilvan had high oleic/low linoleic acid content; therefore it is a highly resistant olive oil against oxidation. Furthermore, the high mean values of total sterols were also obtained for the Mari variety. The oil of the Zard variety from Gilvan had the maximum amount of phenols as a positive quality index. Therefore, the Mari variety, especially from Gilvan has been suggested as a superior cultivar compared to the Zard and Rowghani varieties.
\end{abstract}

KEYWORDS: Chemical composition; Iranian cultivar; Virgin olive oil

RESUMEN: Propiedades químicas de aceites de oliva virgen de cultivares iraníes de las regiones de Fadak y Gilvan. El objetivo de este estudio fue evaluar la composición química (fenoles totales, ácidos grasos, y esteroles) de aceites de oliva virgen iranies (Zard, Rowghani, Mari) cultivados en las regions de Gilvan (provincia de Zanjan) y Fadak (provincia de Qom). Los fenoles totales se determinaron utilizando el método de Folin-Ciocalteu. Los perfiles de ácidos grasos y de esteroles se determinaron mediante cromatografía de gases. En la mayoría de los casos, existen diferencias significativos de los cultivares y los lugares detectados por la composición química $(\mathrm{P}<0,05)$. El análisis de ácidos grasos indicó que la variedad Mari de Gilvan presenta una relación alta oleico/ linoleico; por lo tanto, es un aceite de alta resistencia contra la oxidación. Por otra parte, los valores medios altos de esteroles totales también fueron obtenidos para la variedad Mari. El aceite de la variedad Zard de Gilvan presentó la mayor cantidad de fenoles, considerado este valor como un índice de calidad positivo. La variedad Mari especialmente en Gilvan se sugeriere como un cultivar superior en comparación con las variedades Zard y Rowghani.

PALABRAS CLAVE: Aceite de olive virgin; Composición química; Cultivares iranies

Citation/Cómo citar este artículo: Homapour M, Ghavami M, Piravi-Vanak Z, Hosseini SE. 2014. Chemical properties of virgin olive oil from Iranian cultivars grown in the Fadak and Gilvan regions. Grasas Aceites 65 (4): e043. doi: http:// dx.doi.org/10.3989/gya.0351141.

Copyright: (c) 2014 CSIC. This is an open-access article distributed under the terms of the Creative Commons Attribution-Non Commercial (by-nc) Spain 3.0 Licence. 


\section{INTRODUCTION}

The olive tree (Olea europaea Linn.) is one of the oldest known agricultural trees in the world, and originated in upper Mesopotamia, the maritime parts of Asia Minor and part of northern Iran at the southern coast of the Caspian Sea (Kiralan et al., 2009). Irainan olive oil has received more attention recently as a major component of the Mediterranean diet (Piravi-Vanak et al., 2009). The majority of olive cultivars are located in the north of Iran (Gilan, Golestan and Zanjan) and to a smaller extent in the Khozestan, Qom and Fars regions. The traditional olive varieties grown in Iran include Zard, Rowghani, Mari, Gelooleh, Shengeh, Khormazeitoon, Khara, Dakal, Dezful, and Phishomi. Foreign cultivars namely Koroneiki and Arbequina are also cultivated and harvested in Iran (IOOC, 2012).

Virgin olive oil is acknowledged for its pleasant aroma and flavor, oxidative stability, nutritional and health effects due to its chemical compositions. Fatty acids are the most predominant components in olive oil. The beneficial health-promoting effects of virgin olive oil have been attributed to its high monounsaturated fatty acids (MUFAs) and other natural compounds such as vitamins, polyphenols and other radical scavenging components (AL-Maaitah et al., 2009; Pinelli et al., 2003). Furthermore, it has been reported that the high content of oleic acid might reduce the risk of breast cancer and decrease low density lipoprotein (LDL) cholesterol and triglycerides, hence decreasing blood pressure and cardiovascular disease (Pinelli et al., 2003; Covas et al., 2007). Fatty acid composition also affects the oxidative stability of edible oils; consequently the high resistance of virgin olive oil to oxidation is mainly due to its high oleic acid content (Cinquantaa et al., 2001). This leads to an important commercial benefit of olive oil.

Plant-derived sterols (phytosterols) are the most important portion of the unsaponifiable fraction of lipids present in all plant-based food (Casas et al., 2004). As reported in previous studies, every plant oil has a distinctive sterol profile which is a useful criterion for the classification of virgin olive oils based on their fruit variety (Ben Temime et al., 2008). Additionally, it has been suggested that sterols possess numerous biological characteristics such as cholesterol-lowering, anti-inflammatory and immune regulatory effects (Carr et al., 2010), antihypertensive and antioxidant activity (Yoshida et al., 2003) as well as antimicrobial features; therefore, they are considered as ingredients of functional foods (Ben Temime et al., 2008). Furthermore, the quantitative and qualitative analyses of fatty acids and sterolic composition can be helpful for the detection of authenticity and olive oil adulteration (Al-Ismail et al., 2010).
Virgin olive oil is an important source of phenolic compounds as natural antioxidants (Saitta et al., 2009). Antioxidants can lead to a delay or slow propagation of undesirable changes in shelf life and nutritional properties and they are related to olive oil stability (Boskou, 2006). Furthermore, the antioxidant activity can lead to reduce the risk of oxidative stress and associated diseases such as Alzheimer, cancer, diabetes, rheumatoid, arthritis, inflammatory and cardiovascular diseases (Boskou, 2006; Saitta et al., 2009; Prakash and Kumar, 2011).

The chemical compounds, fatty acid profiles and sterol composition of olive fruits are influenced by several factors. The effects of the nature of the cultivar, crop year (Allalout et al., 2009; Boskou, 2006), geographical region, climate (Piravi et al., 2012), irrigation and water-stress situations (Stefanoudaki et al., 2001), degree of fruit ripeness, processing methods (Morello et al., 2004; Boskou, 2006) and storage conditions (Ben Temime et al., 2008), have been previously reported. Therefore, the diversity of these parameters influences the quality and composition of virgin olive oil in each location. However, there is little scientific evidence about the chemical properties of Iranian virgin olive oils in the Fadak and Gilvan regions. Fadak is considered the most important organic olive farm and Gilvan is the most significant olive cultvation region in Iran. Therefore, the aim of this study is to evaluate the composition of three common Iranian monovarieties (Zard, Rowghani and Mari) in these two top olive harvesting regions. Hence, the effects of environmental conditions and the nature of the olive cultivar on various parameters such as total phenols, fatty acid composition and sterol profiles of olive oils are investigated.

\section{MATERIALS AND METHODS}

\subsection{Sample collection}

Olive fruits (Olea europaea) of three Iranian monovarieties, Mari, Zard and Rowghani were collected from the Fadak farm (Qom Province) and Gilvan (Zanjan Province) in Iran. Sampling was conducted from the $10^{\text {th }}$ of October to the $15^{\text {th }}$ of November in the year 2012. The fresh and undamaged fruits ( $\sim 5 \mathrm{~kg}$ sample) were randomly hand-picked from $\sim 35$ trees at each region of the farm. The maturity index (MI) of olive fruits was approximately 5 , which has been determined according to the following formula (Boskou, 2006):

$$
\begin{aligned}
M I= & (\mathrm{a} \times 0)+(\mathrm{b} \times 1)+(\mathrm{c} \times 2)+(\mathrm{d} \times 3)+(\mathrm{e} \times 4) \\
& +(\mathrm{f} \times 5)+(\mathrm{g} \times 6)+(\mathrm{h} \times 7) / 100
\end{aligned}
$$

Where $a, b, \ldots, h$ are the number of olives in each of the seven color classes from dark green to dark black. After harvesting, the samples were 
transported to the Olive Research Station of Roudbar (Gilan, Iran) within $24 \mathrm{~h}$ for oil extraction.

\subsection{Oil extraction}

Oil extraction was performed using the laboratory oil mill. The olive fruits were crushed in a hammer mill and kneaded for $20 \mathrm{~min}$ at $25^{\circ} \mathrm{C}$. The collected olive pulp was centrifuged at $3000 \mathrm{rpm}$ for 5 min and transferred into dark brown glass bottles and stored at $-20{ }^{\circ} \mathrm{C}$ until experimental studies.

\subsection{Analytical methods}

\subsubsection{Materials}

Silica gel 60 F254 Aluminium sheets, $n$-hexane, $\mathrm{KOH}$, hexane/diethylether (65: 35, v/v), chloroform, methanol and sodium carbonate were purchased from Merck Darmstadt, Germany, gallic acid, Folin-Ciocalteu reagent was obtained from Sigma-Aldrich. All chemical agents were analytical grade.

\subsubsection{Determination of total phenols}

The total phenols of olive oil samples were measured using the Folin-Ciocalteu reagent by spectrophotometer (Shimadzu, model UV-3100, Kyoto, Japan) at $765 \mathrm{~nm}$ as described by Montedoro et al. (1992). The concentration of total phenols was determined using gallic acid for the calibration curve $\left(\mathrm{R}^{2}=0.998\right)$. The analyses were repeated in triplicates for each sample.

\subsubsection{Analysis of sterolic compounds}

Sterols were determined both qualitatively and quantitatively using the IOOC (COI/T.20/Doc. no. 10/Rev. 1, 2001) standard method. The olive oil samples were saponified with an ethanolic potassium hydroxide solution followed by the extraction of the unsaponifiable matter. The sterol fraction was then separated onto a $20 \times 20 \mathrm{~cm}$ thin layer chromatography (TLC) sheet made of silica gel 60 F254. The streols were analyzed by gas chromatography (YL6100GC, Young-Lin Inc., Korea) coupled with an FID detector. The chromatograph was equipped with a TYM5 capillary column $((95 \%)$ dimethyl- $(5 \%)$ diphenylpolysiloxane with a cross linked phase of poly (dimethyldiphenyl) siloxane) of $30 \mathrm{~m}$ in length and an internal diameter of $0.25 \mathrm{~mm}$ and with a uniform thickness between 0.10 to $0.30 \mu \mathrm{m}$. The operating conditions were as follows: column temperature: $260{ }^{\circ} \mathrm{C}$, injector temperature: $280^{\circ} \mathrm{C}$ and detector temperature: $300^{\circ} \mathrm{C}$. The velocity of the carrier gas (Hydrogen) was 10 to $30 \mathrm{~cm} \cdot \mathrm{s}^{-1}$. The amount of injected sample was $2 \mu \mathrm{L}$ with the flow rate of $1 \mu \mathrm{mL} \cdot \mathrm{min}^{-1}$. The quantification was performed by $\alpha$-cholestanol $(0.2 \% \mathrm{w} / \mathrm{v}$, in chloroform $)$ as internal standard.

\subsubsection{Analysis of fatty acids}

The fatty acid analysis was carried out based on the global method IOOC (COI/T.20/Doc. no. 25, 2006). The fatty acid methyl esters were prepared according to IOOC method (COI/T.20/Doc. no. 24, 2002). Methylated fatty acids were analyzed using gas chromatography (YL6500GC, Young-Lin Inc., Korea) equipped with a capillary column CP-Sil 18 $(60 \mathrm{~m} \times 0.25 \mathrm{~mm}$; particle size $)$ and flame ionization detector (FID). Hydrogen was used as the carrier gas and the injection quantity was $1.2 \mu \mathrm{L}$ with a flow rate of $4 \mathrm{~mL} \cdot \mathrm{min}^{-1}$. The temperature conditions of chromatograph were as follows: injector $250{ }^{\circ} \mathrm{C}$, oven $175^{\circ} \mathrm{C}$ (isothermal condition) and detector $300{ }^{\circ} \mathrm{C}$. The results were expressed as the relative percentage of each fatty acid.

Iodine Values (IV) were determined according to the percentages of fatty acids using following formula (Haghighat Kharazi et al., 2012):

$$
\begin{aligned}
\mathrm{IV}= & (\mathrm{C} 16: 1 \%) \times 0.95+(\mathrm{C} 18: 1 \%) \times 0.86+(\mathrm{C} 18: 2 \%) \\
& \times 1.732+(\mathrm{C} 18: 3 \%) \times 2.616
\end{aligned}
$$

The Cox Value (oxidizability) of all olive oil samples was calculated based on the following relation as described by Fatemi and Hammond (1980):

$$
\begin{aligned}
\text { Cox Value }= & {[1(18: 1 \%)+10.3(18: 2 \%)} \\
& +21.6(18: 3 \%)] / 100
\end{aligned}
$$

\subsection{Statistical analysis}

One-way analysis of variance (ANOVA; $P<0.05$ ) was used to compare the data using SPSS 12.0 software (SPSS INC., Chicago, IL, USA, 2002). Significant treatment means were calculated by Duncan's New Multiple Range Test (Haquea et al., 2009). The data are shown as mean values plus standard errors of means.

\section{RESULTS AND DISCUSSION}

\subsection{Total phenolic compounds}

The total phenolic content as the natural antioxidants and quality index of the olive oil was determined using Folin-Ciocalteu by the spectrophotometric assay (Gallina-Toschi et al., 2005; Haghighat Kharazi et al., 2012). As shown in Fig. 1, the significantly $(P<0.05)$ highest concentration of total phenols was detected in the Zard variety of Gilvan $\left(180 \pm 3.00 \mathrm{mg}\right.$ of gallic acid $\mathrm{kg}^{-1}$ of oil $)$ while the significantly $(P<0.05)$ lowest concentrations were found in the Rowghani $(104.00 \pm 4.00 \mathrm{mg}$ of gallic acid $\cdot \mathrm{kg}^{-1}$ of oil) and Mari (113.00 $\pm 3.00 \mathrm{mg}$ 


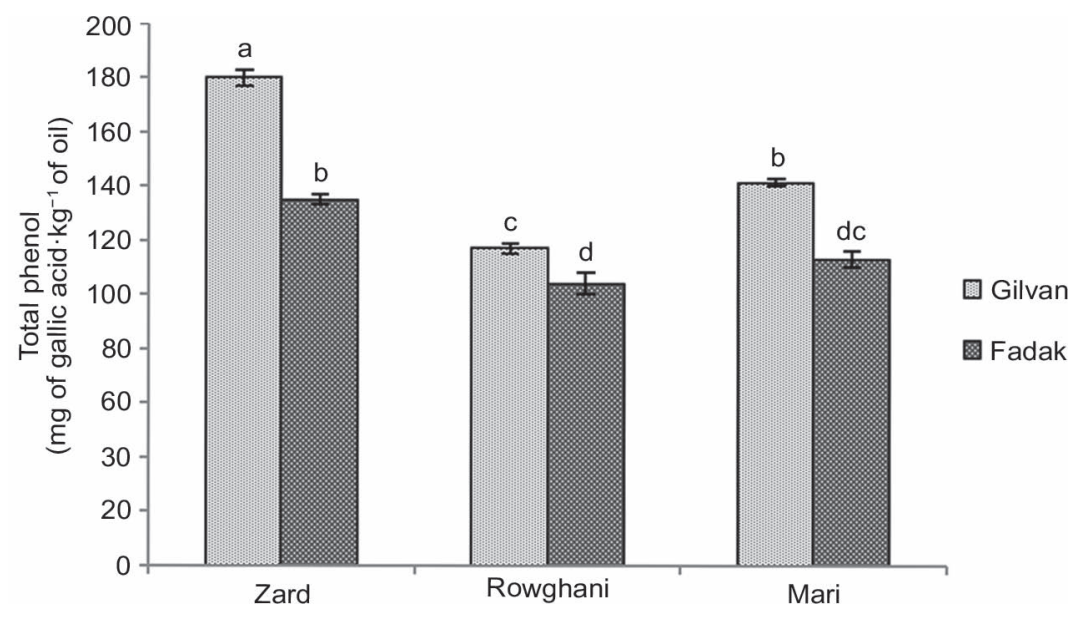

Figure 1. Total phenols of the virgin olive oils from the Fadak and Gilvan regions. Different small letters show significant differences at $P<0.05$.

of gallic acid $\cdot \mathrm{kg}^{-1}$ of oil) cultivars of Fadak. Consequently, this might cause improvements in the oxidative stability of virgin olive oil in the Zard variety of Gilvan. However, other components such as fatty acid composition, tocopherols and the presence of sterolic compounds might also be important factors for these characteristics (Gallina-Toschi et al., 2005). These obtained values were consistent with those reported that the amount of total phenolic compounds in olive oil is variable among different varieties and regions (Haghighat Kharazi et al., 2012).

\subsection{Total sterols}

The sterol fraction in olive oil might be regarded as a major component for detecting adulteration and checking authenticity of all cultivars (Table 1).

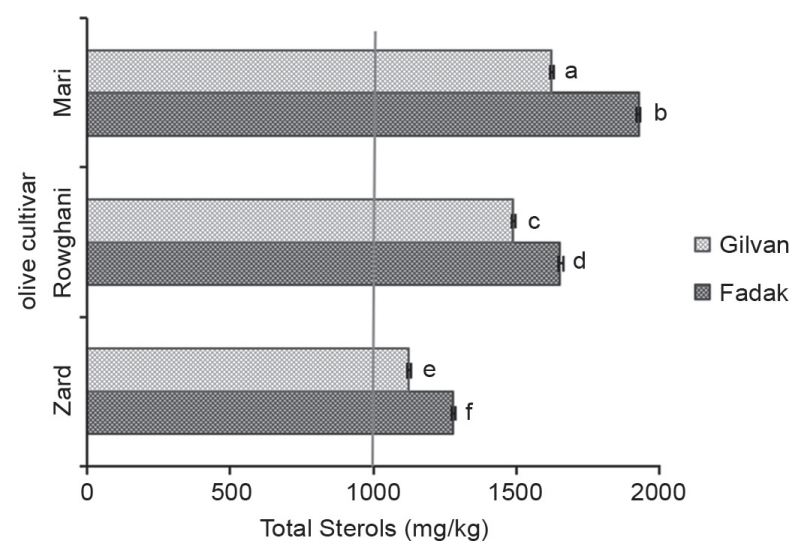

FIGURE 2. Total sterols of the virgin olive oils from the Fadak and Gilvan regions. Different small letters show significant differences at $P<0.05$.
In all varieties, the predominant components of the total sterol fraction were $\beta$-sitosterol, $\Delta 5$-avenasterol and campesterol. The other sterols in trace amounts include cholesterol, brassicasterol, stigmasterol, chlerosterol, stigmastadienol, stigmastenol and $\Delta 7$-avenasterol (Phillips et al., 2002; Cunha et al., 2006).

The data showed that $\beta$-sitosterol is the most abundant sterol in olive oil. The highest $\beta$-sitosterol content was found in the Mari variety of the Fadak region $(92.08 \%)$ and the lowest concentration was in the Rowghani variety of Fadak (87.11\%). In previous studies, it has also been reported that $\beta$-sitosterol accounts for more than $75 \%$ of total sterols (Boskou, 2006; Ben Temime et al., 2008). The obtained data is similar to those published by some authors for virgin olive oil (Phillips et al., 2002; Ben Temime et al., 2008). The health-promoting effects of $\beta$-sitosterol such as lowering plasma cholesterol, preventing different types of cancers (colon, prostate, and breast) has been previously mentioned by Awad et al. (2000), Whiting (2007) and Ben Temime et al. (2008). Regarding the fact that all olive fruits were harvested at the same maturity index (Salvador et al., 2001), the observed differences might be due to cultivar and geographical parameters such as climate and soil type (Cunha et al., 2006).

The levels of $\Delta 5$-avenasterol in olive oil samples were relatively lower than the values reported previously by Ben Temime et al. (2008); Rivera del Alamo et al. (2004) and they are in the range of $1.43 \%$ (Mari cultivar of Gilvan) to $6.39 \%$ (Zard cultivar of Fadak), although they are in agreement with the results obtained by Itoh et al. (1981). The $\Delta 5$-avenasterol content of the Zard variety of Fadak $(6.39 \%)$ was significantly $(P<0.05)$ higher than the other cultivars and the Mari variety of Fadak $(1.78 \%)$ and Gilvan $(1.43 \%)$ were significantly $(P<0.05)$ the 
lowest ones. Wang et al. (2002) reported that $\Delta 5$ avenasterol at elevated temperatures exhibited antioxidant activity and improved oxidative stability in olive oil under frying condition.

As shown in Table 1, the campesterol content of olive oils range from $2.65 \%$ (Rowghani cultivar in Gilvan region) to $5.49 \%$ (Rowghani cultivar of Fadak). According to the Codex Alimentarius and IOOC standard, the maximum concentration of campesterol should be lower than $4 \%$ of the total sterols (Codex, 2003; IOOC, 2011). The mean values for all cultivars $(2.65 \%$ to $3.81 \%)$ except the Rowghani olive oil of Fadak (5.49\%) was in agreement with the standards. Similar values were reported by Ben Temime et al. (2008). Higher values of some virgin olive oil exceeded the upper limit of the international standards such as the Rowghani variety of Fadak in this study, which has also been previously determined by Rivera del Alamo et al. (2004).

Table 1 shows that the values of stigmasterol for the Zard $(0.48 \%)$ and Rowghani $(0.40 \%)$ varieties of Fadak. The acceptable level of stigmasterol according to the Codex Alimentarius and IOOC standard must be less than that of campesterol (Codex, 2003; IOOC, 2011). Our findings indicated a similar result. The data showed that stigmasterol was significantly $(P<0.05)$ affected by the geographical location. Similar findings were previously obtained by Ben Temime et al. (2008) and Salvador et al. (2001). Organoleptic defects and high acidity levels due to high contents of stigmasterol have been given attention in previous studies (Ben Temime et al., 2008). The ratio of campesterol to stigmasterol as the quality index has also been evaluated as shown in Table 1.

The apparent $\beta$-sitosterol (sum of chlerosterol, $\beta$-sitosterol, $\Delta 5$-avenasterol, stigmastadienols and sitostanol) according to the authenticity index must exceed $93 \%$ of total sterols based on the Codex Alimentarius and International Olive Oil Council (IOOC) Standard (Codex, 2003; IOOC, 2011). The obtained data was consistent with the standard values and those reported by Ben Temime et al. (2008).

According to Codex Alimentarius standard, the minimum concentration for total sterols of olive oil is $1000 \mathrm{mg} \cdot \mathrm{kg}^{-1}$ (Codex, 2003). Total sterol concentrations in the varieties examined were found to be greataer than the standard limit and the lowest level was $1123 \mathrm{mg} \cdot \mathrm{kg}^{-1}$ for the Zard variety of Gilvan while the Mari oil of Fadak had a higher quantity of this class compound $\left(1925 \mathrm{mg} \cdot \mathrm{kg}^{-1}\right)$. The antioxidant activity and health-promoting effects of total sterols of olive oil have been already mentioned (Yoshida et al., 2003; Carr et al., 2010); therefore, the Mari oil was evaluated as a good variety, regarding sterols. The findings in this work were in agreement with those reported by Ben Temime et al. (2008) who found that values varied between $1017 \mathrm{mg} \cdot \mathrm{kg}^{-1}$ 
TABLE 2. Fatty acid percentage (mean values $\pm \mathrm{SE}$ ) of virgin olive oils in the Fadak and Gilvan regions

\begin{tabular}{|c|c|c|c|c|c|c|}
\hline & & Fadak & & & Gilvan & \\
\hline & $\mathbf{Z F}$ & RF & MF & ZG & RG & MG \\
\hline C16:0 & $12.85 \pm 0.95^{\mathrm{b}}$ & $18.10 \pm 0.00^{\mathrm{a}}$ & $13.00 \pm 0.60^{\mathrm{b}}$ & $13.10 \pm 0.30^{b}$ & $16.75 \pm 0.15^{\mathrm{a}}$ & $11.4 \pm 0.10^{\mathrm{b}}$ \\
\hline C16:1t & $0.05 \pm 0.05^{\mathrm{a}}$ & $0.10 \pm 0.00^{\mathrm{a}}$ & $0.10 \pm 0.00^{\mathrm{a}}$ & $0.05 \pm 0.05^{\mathrm{a}}$ & $0.05 \pm 0.05^{\mathrm{a}}$ & $0.01 \pm 0.00^{\mathrm{a}}$ \\
\hline $\mathrm{C} 16: 1 \mathrm{c}$ & $1.10 \pm 0.10^{\mathrm{b}}$ & $1.40 \pm 0.00^{\mathrm{a}}$ & $1.15 \pm 0.05^{\mathrm{b}}$ & $1.15 \pm 0.05^{\mathrm{b}}$ & $1.40 \pm 0.10^{\mathrm{a}}$ & $0.95 \pm 0.05^{\mathrm{b}}$ \\
\hline $\mathrm{C} 17: 0$ & - & - & - & - & - & - \\
\hline $\mathrm{C} 17: 1$ & - & $0.10 \pm 0.00^{\mathrm{a}}$ & $0.10 \pm 0.00^{\mathrm{a}}$ & $0.10 \pm 0.00^{\mathrm{a}}$ & - & $0.01 \pm 0.00^{\mathrm{a}}$ \\
\hline C18:0 & $3.05 \pm 0.15^{\mathrm{a}}$ & $2.80 \pm 0.00^{\mathrm{b}}$ & $2.30 \pm 0.00^{\mathrm{d}}$ & $2.75 \pm 0.05^{\mathrm{bc}}$ & $2.90 \pm 0.00^{\mathrm{ab}}$ & $2.55 \pm 0.05^{\mathrm{c}}$ \\
\hline C18:1 & $66.25 \pm 0.85^{\mathrm{d}}$ & $57.00 \pm 0.00^{\mathrm{e}}$ & $74.75 \pm 0.45^{\mathrm{b}}$ & $69.05 \pm 0.25^{\mathrm{c}}$ & $58.25 \pm 0.05^{\mathrm{e}}$ & $76.90 \pm 0.1^{\mathrm{a}}$ \\
\hline C18:2 & $15.40 \pm 0.2^{\mathrm{c}}$ & $18.70 \pm 0.00^{\mathrm{b}}$ & $7.10 \pm 0.00^{\mathrm{e}}$ & $12.55 \pm 0.05^{\mathrm{d}}$ & $19.05 \pm 0.05^{\mathrm{a}}$ & $6.70 \pm 0.00^{\mathrm{g}}$ \\
\hline C18:3 & $0.40 \pm 0.00^{\mathrm{a}}$ & $0.40 \pm 0.00^{\mathrm{a}}$ & $0.35 \pm 0.00^{\mathrm{a}}$ & $0.40 \pm 0.00^{\mathrm{a}}$ & $0.40 \pm 0.00^{\mathrm{a}}$ & $0.40 \pm 0.00^{\mathrm{a}}$ \\
\hline $\mathrm{C} 20: 0$ & $0.25 \pm 0.05^{\mathrm{a}}$ & $0.20 \pm 0.00^{\mathrm{a}}$ & $0.20 \pm 0.00^{\mathrm{a}}$ & $0.20 \pm 0.00^{\mathrm{a}}$ & $0.20 \pm 0.00^{\mathrm{a}}$ & $0.25 \pm 0.05^{\mathrm{a}}$ \\
\hline C20:1 & $0.60 \pm 0.00^{\mathrm{bc}}$ & $0.90 \pm 0.00^{\mathrm{a}}$ & $0.65 \pm 0.05^{\mathrm{b}}$ & $0.55 \pm 0.05^{\mathrm{bc}}$ & $0.60 \pm 0.00^{\mathrm{bc}}$ & $0.50 \pm 0.00^{\mathrm{c}}$ \\
\hline $\mathrm{C} 22: 0$ & $0.05 \pm 0.05^{\mathrm{a}}$ & $0.10 \pm 0.00^{\mathrm{a}}$ & $0.10 \pm 0.00^{\mathrm{a}}$ & $0.10 \pm 0.00^{\mathrm{a}}$ & $0.05 \pm 0.05^{\mathrm{a}}$ & $0.15 \pm 0.05^{\mathrm{a}}$ \\
\hline C22:1 & - & $0.30 \pm 0.00^{\mathrm{a}}$ & - & - & $0.35 \pm 0.00^{\mathrm{a}}$ & - \\
\hline SFA & $16.20 \pm 1.10^{\mathrm{b}}$ & $21.20 \pm 0.00^{\mathrm{a}}$ & $15.60 \pm 0.60^{\mathrm{b}}$ & $16.10 \pm 0.35^{\mathrm{b}}$ & $19.90 \pm 0.10^{\mathrm{a}}$ & $14.35 \pm 0.05^{\mathrm{b}}$ \\
\hline UFA & $83.8 \pm 1.10^{\mathrm{b}}$ & $78.90 \pm 0.00^{\mathrm{c}}$ & $84.2 \pm 0.40^{\mathrm{ab}}$ & $83.8 \pm 0.35^{\mathrm{b}}$ & $80.10 \pm 0.10^{c}$ & $85.6 \pm 0.05^{\mathrm{a}}$ \\
\hline MUFA & $68.00 \pm 0.90^{\mathrm{d}}$ & $59.80 \pm 0.00^{\mathrm{e}}$ & $76.75 \pm 0.35^{\mathrm{b}}$ & $70.90 \pm 0.3^{\mathrm{c}}$ & $60.65 \pm 0.15^{\mathrm{e}}$ & $78.55 \pm 0.05^{\mathrm{a}}$ \\
\hline PUFA & $15.80 \pm 0.20^{\mathrm{c}}$ & $19.10 \pm 0.00^{\mathrm{b}}$ & $7.45 \pm 0.05^{\mathrm{e}}$ & $12.95 \pm 0.05^{\mathrm{d}}$ & $19.45 \pm 0.05^{\mathrm{a}}$ & $7.10 \pm 0.00^{\mathrm{g}}$ \\
\hline SFA/UFA & $0.19 \pm 0.15^{\mathrm{b}}$ & $0.27 \pm 0.00^{\mathrm{a}}$ & $0.19 \pm 0.01^{\mathrm{b}}$ & $0.19 \pm 0.01^{\mathrm{b}}$ & $0.284 \pm 0.00^{\mathrm{a}}$ & $0.167 \pm 0.00^{\mathrm{b}}$ \\
\hline MUFA/PUFA & $4.30 \pm 0.00^{\mathrm{d}}$ & $3.13 \pm 0.00^{\mathrm{e}}$ & $10.3 \pm 0.02^{\mathrm{b}}$ & $5.47 \pm 0.00^{\mathrm{c}}$ & $3.11 \pm 0.02^{\mathrm{e}}$ & $11.06 \pm 0.01^{\mathrm{a}}$ \\
\hline Oleic/Linoleic & $4.30 \pm 0.00^{\mathrm{d}}$ & $3.04 \pm 0.00^{\mathrm{e}}$ & $10.52 \pm 0.06^{\mathrm{b}}$ & $5.50 \pm 0.00^{\mathrm{c}}$ & $3.05 \pm 0.01^{\mathrm{e}}$ & $11.47 \pm 0.02^{\mathrm{a}}$ \\
\hline Cox Value & $2.33 \pm 0.03^{\mathrm{c}}$ & $2.58 \pm 0.00^{\mathrm{b}}$ & $1.55 \pm 0.02^{\mathrm{e}}$ & $2.06 \pm 0.01^{\mathrm{d}}$ & $2.63 \pm 0.01^{\mathrm{a}}$ & $1.54 \pm 0.00^{\mathrm{e}}$ \\
\hline IV & $85.73 \pm 1.17^{\mathrm{a}}$ & $83.78 \pm 0.00^{\mathrm{bc}}$ & $78.59 \pm 0.47^{\mathrm{d}}$ & $83.26 \pm 0.25^{\mathrm{c}}$ & $85.74 \pm 0.22^{\mathrm{ab}}$ & $79.69 \pm 0.39^{\mathrm{d}}$ \\
\hline
\end{tabular}

ZF, Zard variety of Fadak; RF, Rowghani variety of Fadak; MF, Mari variety of Fadak; ZG, Zard variety of Gilvan; RG, Rowghani variety of Gilvan; MG, Mari variety of Gilvan.

SFA, Saturated fatty acid; UFA, Unsaturated fatty acid; MUFA, Monounsaturated fatty acid; PUFA, Polyunsaturated fatty acid; IV, Iodine Value.

Values with different small letters in a same row are significantly different at $P<0.05$.

and $1522 \mathrm{mg} \cdot \mathrm{kg}^{-1}$, but our results were low compared with Alves et al. (2005) who found the total content of sterol to range from 2003 to $2682 \mathrm{mg} \cdot \mathrm{kg}^{-1}$.

\subsection{Fatty acid composition}

Table 2 presents the fatty acid composition of olive oil cultivars in both regions. The predominant fatty acid of all cultivars is oleic acid followed by lower concentrations of linoleic, palmitic, stearic and palmitoleic acids with traces of linolenic and arachidic acids. The obtained results are consistent with previously published literature (Aguilera et al., 2005; Hashempour et al., 2010; Haghighat Kharazi et al., 2012).

The amount of palmitic acid, the major saturated fatty acid, is found in the range of $11.4 \%$ to
$18.1 \%$, which is in accordance with the IOOC and Codex standard (7.5-20\%). As shown in Table 2, the least mean palmitic acid content was determined in the Mari variety of Gilvan as the low mean annual temperature. Ranalli et al. (1999) and Kiralan et al. (2009) noted that fatty acid composition is temperature dependent and as the temperature decreases the saturated fatty acid contents increase.

The mean values of oleic acid as the predominant fatty acid were in the range of $57 \%$ to $76 \%$ (Table 2) according to olive oil Codex standard (Codex, 2003) and IOOC regulations (IOOC, 2011). In the previous studies, the amounts of oleic acid of Iranian cultivars were also aligned with the international regulations (Hashempour et al., 2010; Haghighat Kharazi et al., 2012). Besides, changes in oleic acid contents were observed in different varieties of olive 
oil, which might be due to the diversity of cultivars and environment conditions. The Mari variety of Gilvan $(76.90 \pm 0.10)$ achieved the highest mean value $(P<0.05)$. The data indicated that the oleic acid content of each variety in Gilvan with a higher annual mean temperature is significantly $(P<0.05)$ higher than that obtained from the Fadak region. This is in agreement with previous studies which also reported that the increase in environmental temperature leads to a decrease in the oleic acid content (Rondanini et al., 2011). High oleic acid content leads to an increase in oxidative stability and antihypertensive activity and LDL cholesterol lowering effects have been shown (Psaltopoulou et al., 2004).

Based on the obtained data, the percentage of linoleic acid $(6.7 \%$ to $19.05 \%)$ was in agreement with the Codex standard and IOOC regulation (3.5 to $21 \%$ ). The Mari variety of Gilvan contains the significantly lowest linoleic acid content $(P<0.05)$ among all other olive samples. Rondanini et al. (2011) stated that there is a negative correlation between oleic acid and linoleic acid contents of olive oils which is in accordance with our findings. The ratio of oleic to linoleic acid was also in the range of $3.04 \%$ to $11.47 \%$ and the Mari variety of Gilvan showed the highest mean value. Consequently, the variation in oleic and linoleic compositions may be explained by different enzyme activities during triacylglycerol biosynthesis for each cultivar (Hashempour et al., 2010).

There were no significant differences $(P \geq 0.05)$ between cultivars regarding linolenic acid contents. Moreover, linolenic acid contents of the all cultivars were in accordance with the standards (Codex: $<1.5$ and IOOC: $\leq 1$ ). In the current study, the cultivars with low levels of linoleic and palmitic acids showed concurrently high oleic acid contents such as the Mari variety of Gilvan, which has been also published by other researchers (Rondanini et al., 2011).

The level of palmitoleic acid as a minor fatty acid in olive oil ranged from $0.95 \%$ to $1.40 \%$. The Rowghani variety of Gilvan and Fadak had significantly the highest concentrations among all cultivars $(P<0.05)$. The average content of palmitoleic acid was consistent with those established by the Codex standard and IOOC regulation (0.3-3.5\%).

As shown in Table 2 the stearic acid content was $0.35 \%$ to $3.05 \%$, which is in the range of the criteria established in the IOOC and Codex $(0.5-5 \%)$. The results also showed that the Mari variety of Fadak $(2.30 \pm 0.00)$ had the lowest stearic acid content while the Zard variety of Fadak $(3.05 \pm 0.15)$ contained the highest amount $(P<0.05)$. In general, the ratio of saturated to unsaturated (S/US) fatty acids was $0.167 \%$ to $0.284 \%$ and the Mari variety of Gilvan had the lowest mean value due to the lower content of palmitic and stearic acids.
Based on our findings, the Iodine Values ranged from 78 for the Mari variety of Fadak to 85 for the Zard variety of Fadak and were in agreement with the Codex standard (75-94). Significant differences $(P<0.05)$ were observed among all cultivars and locations (except for the Mari cultivar). The lowest mean for Iodine Values was obtained for the Mari varieties of Fadak and Gilvan (Table 2), however the unsaturated fatty acids of this cultivar were at the highest concentrations. This might be attributed to the ratio of oleic to linoleic acid, which is higher than other olive oils in the current study; therefore, it means that the percentage of monounsaturated fatty acid is greater than polyunsaturated fatty acid in this variety. As a result, the above-mentioned olive oils are more resistant to oxidation. The Cox Value as a determinant factor in oil stability also confirmed the obtained results. On the other hand, the Mari cultivars of Gilvan (1.54) and Fadak (1.55) which had the lowest value are more stable than other olive oil samples. In contrast, the highest Cox Value was observed in the Rowghani oil of Gilvan (2.63) due to its high content of polyunsaturated fatty acid, especially linoleic acid. Haghighat Kharazi et al. (2012) also found that the oil of the Mari cultivar is more stable against oxidation than the Zard and Phishomi oils.

\section{CONCLUSIONS}

A study on Iranian virgin olive oil (Zard, Rowghani and Mari) in Gilvan (Zanjan Province) and Fadak (Qom Province) revealed that the total phenols, fatty acid profile and sterol composition of olive oils correspond with the standards of Codex Alimentaurious except for the Rowghani olive oil of Fadak regarding to campesterol. The results suggested that not only olive cultivars, but also the climate of the growing region of olive fruits plays important roles in the chemical composition of fruit and consequently the extracted oil. The fatty acid analysis, Iodine and Cox Value showed that Mari oil is superior to Zard and Rowghani oils regarding oxidative stability, especially at the Gilvan location. In the current study, the Mari variety of Fadak showed significantly the highest total content of sterols $(P<0.05)$ as compared to other samples. Therefore, the Mari cultivar was recommended as a superior cultivar compared to Zard and Rowghani, especially in Gilvan. Further study is required to obtain data on the characteristics of these Iranian cultivars (Zard, Rowghani and Mari) and also foreign cultivars grown in other regions of Iran. Additionally, it has been suggested that the evaluation of other chemical compositions of Iranian olive oils such as pigments, tocopherol concentrations and organoleptic qualities of oils is necessary. 


\section{ACKNOWLEDGMENTS}

The support of Islamic Azad University, Science and Research Branch of Tehran and Institute of Standards and Industrial Research of Iran are gratefully acknowledged.

\section{REFERENCES}

Aguilera MP, Beltran G, Ortega D, Fernandez A, Jimenez A, Uceda M. 2005. Characterization of virgin olive oil of Italian olive cultivars "Frantoio" and "Leccino" grown in Andalusia. Food Chem. 89, 387-391. http://dx.doi. org/10.1016/j.foodchem.2004.02.046.

Al-Ismail KM, Alsaed AK, Rafat A, Al-Dabbas M. 2010. Detection of olive oil adulteration with some plant oils by GLC analysis of sterols using polar column. Food Chem. 121,1255-1259.http://dx.doi.org/10.1016/j.foodchem.2010. 01.016 .

Allalout A, Krichène D, Methenni K, Taamalli A, Oueslati I, Daoud D, Zarrouk M. 2009. Characterization of virgin olive oil from super intensive Spanish and Greek varieties grown in northern Tunisia. Scientia Horticulturae. 120, 77-83. http://dx.doi.org/10.1016/j.scienta.2008.10.006.

AL-Maaitah MI, AL-Absi KM, AL-Rawashdeh A. 2009. Oil quality and quantity of three olive cultivars as influence by harvesting date in the middle and southern parts of Jordan. Int. J. Agr. Biol. 11, 266-272.

Alves MR, Cunha SC, Amaral JS, Pereira JA, Oliveira MB. 2005. Classification of PDO olive oils on the basis of their sterol composition by multivariate analysis. Anal Chim Acta. 549, 166-178. http://dx.doi.org/10.1016/j.aca.2005.06.033.

Awad AB, Chan KC, Downie AC, Fink CS. 2000. Peanuts as a source of $\beta$-sitosterol, a sterol with anticancer properties. Nutr. Cancer. 36, 238-241. http://dx.doi.org/10.1207/ S15327914NC3602 14.

Ben Temime S, Manai $\bar{H}$, Methenni K, Baccouri B, Abaza L, Daoud D, Casas JS, Bueno EO, Zarrouk M. 2008. Sterolic composition of Che'toui virgin olive oil: Influence of geographical origin. Food Chem. 110, 368-374. http://dx.doi. org/10.1016/j.foodchem.2008.02.012.

Boskou D. 2006. Sources of natural phenolic antioxidants. Trends in Food Sci. Techn. 17, 505-512.

Carr. AS, Cardwell CR, McCarron PO, McConville J. 2010. A systematic review of population based epidemiological studies in Myasthenia Gravis. BMC Neurology. doi: 10.1186/14712377-10-46. http://dx.doi.org/10.1186/1471-2377-10-46.

Carr TP, Ash MM, Brown A. 2010. Cholesterol-lowering phytosterols: factors affecting their use and efficacy. Nutrition and Dietary Supplements. 2, 59-72. http://dx.doi.org/10.2147/ NDS.S10974.

Casas JS, Bueno EO, Montano Garcia AM, Cano MM. 2004. Sterol and erythrodiol + uvaol content of virgin olive oils from cultivars of Extremadura (Spain). Food Chem. 87, 225230. http://dx.doi.org/10.1016/j.foodchem.2003.11.012.

Cinquantaa L, Estia M, Di Matteob M. 2001. Oxidative stability of virgin olive oils. J. Am. Oil Chem. Soc. 78, 1197-1202. http://dx.doi.org/10.1007/s11745-001-0413-x.

Covas MI. 2007. Olive oil and the cardiovascular system. Pharmaco Res. 55, 175-186. http://dx.doi.org/10.1016/j. phrs.2007.01.010

Codex. 2003. Olive oils and olive pomace oils. Codex Stan. 33-1981.

Cunha SS, Fernandes JO, Oliveira MB. 2006. Quantification of free and esterified sterols in Portuguese olive oils by solidphase extraction and gas chromatography-mass spectrometry. J. Chromatogr. A. 1128, 220-227. http://dx.doi. org/10.1016/j.chroma.2006.06.039

Fatemi SH, Hammond EG. 1980. Analysis of oleate, linoleate and linolenate hydroperoxides in oxidized ester mixtures. Lipids. 15, 379-385. http://dx.doi.org/10.1007/ BF02533555.

Gallina-Toschi T, Cerretani L, Bendini A, Bonoli-Carbognin M, Lercker G. 2005. Oxidative stability and phenolic content of virgin olive oil: An analytical approach by traditionaland high resolution techniques. J. Sep. Sci. 28, 859-870. http://dx.doi.org/10.1002/jssc.200500044

Haghighat-Kharazi S, Esmaeilzadeh Kenari R, Raftani Amiri Z, Azizkhani M. 2012. Characterization of Iranian virgin olive oil from the Roodbar region: A study on Zard, Mari and Phishomi. J. Am. Oil Chem. Soc. 89, 1241-1247.

Haquea M, Chinb HC, Huanga H. 2009. Modeling fault among motorcyclists involved in crashes. Accident Anal Prev. 41, 327-335. http://dx.doi.org/10.1016/j.aap.2008.12.010.

Hashempour M, Fotouhi Ghazvini R, Bakhshi D, Aliakbar A, Papachatzis A, Kalorizou H. 2010. Characterization of virgin olive oils (Olea europaea L.) from three main Iranian cultivars, 'Zard', 'Roghani' and 'Mari' in Kazeroon Region. Biotechnol. Biotec. Eq. 24, 2080-2084. http://dx.doi. org/10.2478/V10133-010-0053-Z.

International Olive Council. (2012). General description of olive growing in Iran.

International Olive Council- Decision COI/T.15/NC No3/Rev. 6 November 2011, Trade Standard Applying to Olive oils and Olive -pomace oils.

Itoh T, Yoshida K, Yatsu T, Tamura T, Matsumoto T. 1981. Triterpene Alcohols and Sterols of Spanish Olive Oil. $J$. Am. Oil Chem. Soc. 58, 545-550. http://dx.doi.org/10.1007/ BF02541591.

Kiralan M, Bayrak A, Mucahit TO. 2009. Oxidation stability of virgin olive oils from some important cultivars in East Mediterranean area in Turkey. J. Am. Oil Chem. Soc. 86, 247-252. http://dx.doi.org/10.1007/s11746-008-1337-4.

Montedoro GF, Servili M, Baldioli M, Maniati E. 1992. Simple and hydrolysable phenolic compounds in Virgin olive oil by HPLC. J. Agric. Food Chem. 40, 1571-1576. http://dx.doi. org/10.1021/jf00021a019.

Morello JR, Motilva MJ, Tovar MJ, Romero MP. 2004. Changes in commercial virgin olive oil (Cv. Arbequina) during storage, with special emphasis on the phenolic fraction. Food Chem. 85, 357-364. http://dx.doi.org/10.1016/j. foodchem.2003.07.012

Phillips KM, Ruggio DM, Toivo JI, Swank MA, Simpkins AH 2002. Free and esterified sterol composition of edible oils and fats. J. Food Compos. Anal. 15, 123-142. http://dx.doi. org/10.1006/ifca.2001.1044.

Pinelli P, Galardi C, Mulinacci N, Vincieri FF, Cimatob A, Romani A. 2003. Minor polar compound and fatty acid analyses in monocultivar virgin olive oils from Tuscany. Food Chem. 80, 331-336. http://dx.doi.org/10.1016/ S0308-8146(02)00268-6.

Piravi-Vanak Z, Ghavami M, Ezzatpanah H, Arab J, Safafar H, Ghasemi JB. 2009. Evaluation of authenticity of Iranian olive oil by fatty acid and triacylglycerol profiles. J. Am. Oil Chem. Soc. 86, 827-833. http://dx.doi.org/10.1007/ s11746-009-1419-y.

Piravi-Vanak Z, Ghasemi JB, Ghavami M, Ezzatpanah H, Zolfonoun, E. 2012. The Influence of Growing Region on Fatty Acids and Sterol Composition of Iranian Olive Oils By Unsupervised Clustering Methods. J. Am. Oil Chem. Soc. 89, 371-378. http://dx.doi.org/10.1007/ s11746-011-1922-9.

Prakash D, Kumar N. 2011. Cost effective natural antioxidants nutrients, in Watson RR, Gerald JK, Preedy VR (Ed.) Dietary supplements, and nutriceuticals, Humana Press., New York, pp. 163-169. http://dx.doi. org/10.1007/978-1-60761-308-4-12.

Psaltopoulou T, Naska A, Orfanos P, Trichopoulos D, Mountokalakis T, Trichopoulou A. 2004. Olive oil, the Mediterranean diet, and arterial blood pressure: the Greek European prospective investigation into cancer and nutrition (EPIC) study. Am. J. Clin. Nutr. 80, 1012-1018.

Ranalli A, De-Mattia G, Patumi M, Proietti P. 1999. Quality of virgin olive oil as influenced by origin area. Grasas Aceites. 50, 249-259. http://dx.doi.org/10.3989/gya.1999. v50.i4 663 .

Rivera del Álamo R, Fregapane G, Aranda F, Gómez-alonso S, Salvador MD. 2004. Sterol composition of Cornicabra virgin olive oil: the campesterol content exceeds the upper limit of $4 \%$ established by EU regulations. 
Food Chem. 84, 533-537. http://dx.doi.org/10.1016/ S0308-8146(03)00275-9.

Rondanini DP, Castro DN, Searles PS, Rousseaux MC. 2011. Fatty acid profiles of varietal virgin olive oils (Olea europaea L.) from mature orchards in warm arid valleys of Northwestern Argentina (La Rioja). Grasas Aceites. 62, 399-409. http://dx.doi.org/10.3989/gya.125110.

Saitta M, Salvo F, Di Bella G, Dugo G, La Torre GL. 2009. Minor compounds in the phenolic fraction of virgin olive oils, Food Chem. 112, 525-532. http://dx.doi.org/10.1016/j. foodchem.2008.06.001.

Salvador MD, Aranda F, Fregapane G. 2001. Influence of fruit ripening on 'Coronicabra' virgin olive oil quality: A study of four successive crop seasons. Food Chem. 73, 45-73. http://dx.doi.org/10.1016/S0308-8146(00)00276-4.
Stefanoudaki E, Chartzoulakis K, Koutsaftakis A, Kotsifaki F. 2001. Effect of drought on qualitative characteristics of olive oil of cv Koroneiki. Grasas Aceites. 52, (3-4), 202206. http://dx.doi.org/10.3989/gya.2001.v52.i3-4.358

Yoshida Y, Niki E, Noguchi N. 2003. Comparative study on the action of tocopherols and tocotrienols as antioxidant: chemical and physical effects. Chem. Phys. Lipids. 123, 63-75. http://dx.doi.org/10.1016/S0009-3084(02)00164-0.

Wang T, Hicks KB, Moreau R. 2002. Antioxidant activity of phytosterols, oryzanol and other phytosterol conjugates. J. Am. Oil Chem. Soc. 79, 1201-1206. http://dx.doi. org/10.1007/s11746-002-0628-x

Whiting S. 2007. Healthy living made easy: The only things you need to know about diet. Morgan James Publishing. New York, USA. pp. 7-8. 